\title{
Impact of Secondary and Micronutrients on Productivity and Quality of Bt Cotton: A Review
}

\author{
D. Swetha*, P. Laxminarayana, G. E. C. H. Vidyasagar, S. Narender Reddy and Harish Kumar Sharma
}

Dept. of Agronomy, College of Agriculture, Rajendranagar, Telangana (500 030), India

\section{Corresponding Author}

D. Swetha

e-mail: swetha.dasari21@gmail.com

\author{
Article History \\ Article ID: IJEP0364 \\ Received in 09 ${ }^{\text {th }}$ March, 2020 \\ Received in revised form $25^{\text {th }}$ March, 2020 \\ Accepted in final form $03^{\text {rd }}$ April, 2020
}

\begin{abstract}
Secondary and micronutrients are essential elements that are used by plants in small quantities. Yield and quality of agricultural products increased with secondary and micronutrients application, therefore human and animal health is protected.. Secondary (Ca, Mg, S) and micronutrients especially Zn, B are essential for higher productivity of cotton. Magnesium is essential for the production of the green pigment in chlorophyll, which is the driving force for photosynthesis. It is also essential for the metabolism of carbohydrates (sugars), for cell division and protein formation. Zinc is an element directly affects yield and quality because of functions such as activity in biological membrane stability, enzyme activation ability and auxin synthesis, while, boron plays an essential role in the development and growth of new cells in the growing meristem and also required for protein synthesis where nitrogen and carbohydrates are converted into protein. This article reviews the influence of $\mathrm{Mg}, \mathrm{Zn}$ and $\mathrm{B}$ application on yield and quality aspects of $\mathrm{Bt}$ cotton.
\end{abstract}

Keywords: Boron, magnesium, micro-nutrients, secondary nutrient, zinc

\section{Introduction}

Enhancing the productivity is a prime objective to feed the ever growing population from the shrinking natural resources. In developing countries like India, sustainable productivity requires that, more production per unit of inputs with minimum environmental degradation. Since, the fertilizer application has been linked with real or imaginary degradation of environmental quality, fertilizers play an important role in the production and productivity of the crops but continuous and imbalanced use of high analysis fertilizers alone over a longer period adversely affected the soil health and production potential. Prevailing changes in climatic condition, occurrence of environmental stress in major of production factors (irrigation and nutrient management), degrading soil fertility by indiscriminate use of high analysis fertilizers without organic manures, complex fertilizers, imbalanced use of fertilizers lead to problems like declining organic matter and mining of nutrients especially those which are not applied in sufficient quantities (potassium). This has lead to an era of multi nutrient deficiencies and deficiencies of at least six elements viz., nitrogen, phosphorus, potassium, sulphur, zinc and boron are widespread. Secondary ( $\mathrm{Ca}$, $\mathrm{Mg}, \mathrm{S}$ ) and micronutrients especially $\mathrm{Zn}, \mathrm{B}$ are essential for higher productivity of cotton. Besides increasing nutrient use efficiency, Magnesium is essential for the production of the green pigment in chlorophyll, which is the driving force for photosynthesis. It is also essential for the metabolism of carbohydrates (sugars), for cell division and protein formation. It is an enzyme activator in the synthesis of nucleic acids (DNA and RNA). It regulates uptake of the other essential elements, serves as a carrier of phosphate compounds throughout the plant, facilitates the translocation of carbohydrates (sugars and starches) and enhances the production of oils and fats. Phosphorus uptake could not occur without magnesium and vice versa.

Micronutrient deficiencies not only hamper crop productivity but also deteriorate produce quality. Though their requirement is small, however, they act as a catalyst in the uptake and use of macronutrients. Nutritional status of plants has a considerable impact on partitioning of carbohydrates and dry matter between plant shoots and roots. The increasing deficiencies of these nutrients started affecting the crop growth and yields and low response to their applications are being noticed. Zinc has important functions in protein and carbohydrate metabolism of plant. Furthermore, zinc is an element directly affects yield and quality because of functions such as activity in biological membrane stability, enzyme activation ability and auxin synthesis, while boron plays an essential role in the development and growth of new cells in the growing meristem and also required for protein synthesis where nitrogen and carbohydrates are converted into protein. It also plays an essential role in plant cell formation, integrity of plasma membranes, pollen tube growth and increases pollination and seed development. The impact of application 
of major nutrients on cotton and other crops has been well established. Hence, we have reviewed the importance and impact of $\mathrm{Mg}, \mathrm{Zn}$ and $\mathrm{B}$ nutrition on growth, productivity and quality of $B t$ cotton in this article.

\section{Effect of Secondary and Micro Nutrients on Growth and Growth Parameters}

The highest plant height, number of monopodial branches and number of sympodial branches were observed due to foliar application from $2000 \mathrm{cc} \mathrm{ha}^{-1}$ boron at pre-flowering (PF) stage (Karademir and Karademir, 2020). Raj and Chandrasekar (2019) reported that higher plant height, number of monopodial branches, sympodial branches, LAI, LAD and SPAD chlorophyll meter value than other concentrations due to foliar application of nano ZnO @ 1000 ppm. More et al. (2018) reported that application of $125 \%$ RDF+foliar spraying of $0.5 \%$ Zinc $+0.2 \%$ Boron twice during flowering (60 DAS) and boll development stage (80 DAS) recorded significantly maximum growth attributes but it was at par with the 125\% RDF + foliar spraying of $0.2 \%$ of Boron and $125 \%$ RDF +foliar spraying $0.5 \%$ Zinc. A field experiment was conducted at Raichur to evaluate the effect of nutrient management practices on leaf reddening on $B t$ cotton and results revealed that 3 foliar sprays of $\mathrm{MgSO}_{4}+\mathrm{KNO}_{3}, \mathrm{MgSO}_{4}+19: 19: 19$ NPK along with soil application of $\mathrm{MgSO}_{4}$ during flowering, boll formation and boll development stages, reduced the LRI by 18.7 and $16.2 \%$ at 135 DAS and 12.7 and $11.5 \%$ at harvest stages, respectively as compared with control (Santhosh et al., 2015).Reddening in $B t$ cotton leaves was reduced by 30 to $40 \%$ with foliar application of urea @ 2\% + DAP @ 2\%+MgSO @ 1\% at boll formation stage (CICR, 2009).

\section{Effect of Secondary and Micro Nutrients on Dry Matter Production}

Application of $125 \%$ RDF + foliar spraying of $0.5 \%$ Zinc $+0.2 \%$ Boron twice during flowering (60 DAS) and boll development stage (80 DAS) resulted in significantly high dry matter plant $^{-1}$ (More et al., 2018). Shivamurthy and Biradar (2014) conducted experiment at Dharwad during Kharif in medium black soil and the results revealed that application of $1 \%$ of 19:19:19 water soluble fertilizer at 70, 90 and 110 DAS along with RDF+FYM+1\% $\mathrm{MgSO}_{4}$ with three sprays at 70, 90 and 110 DAS recorded significantly higher dry matter production as compared to other nutritional treatments. Sankaranarayanan et al. (2010) recorded that foliar application of $\mathrm{MgSO}_{4} @ 0.5 \%$ at 60, 75 and 90 days after planting significantly influenced the leaf area index, bolls plant ${ }^{-1}$ and dry weight at 90 days after planting by 26,30 and $27 \%$ over control. A field experiment conducted by Ratna Kumari and Hema (2009) at RARS, Guntur, to study the effect of foliar application of different nutrient concentrations $\left(\mathrm{MgSO}_{4} @ 0.5\right.$ and 1\%, $\mathrm{ZnSO}_{4} @ 0.2 \%, \mathrm{FeSO}_{4}$ @ 0.2 and $0.4 \%, \mathrm{MgSO}_{4} @ 0.2$ and 0.4\%, boric acid @ 0.2\%) and observed that application of $\mathrm{Fe}, \mathrm{Zn}$ and $\mathrm{Mn}$ resulted in increased branches plant ${ }^{-1}$, and bolls plant ${ }^{-1}$ whereas no significant effect was found with plant height of cotton.

\section{Effect of Secondary and Micro Nutrients on Yield and Yield Attributes of Cotton}

Significantly higher number of bolls, boll weight, number of seeds boll-1, 100 seeds weight and seed cotton yield obtained from $2000 \mathrm{cc} \mathrm{ha}^{-1}$ boron application to leaves at pre-flowering (PF) stage (Karademir and Karademir, 2020). Raj and Chandrasekar (2019) reported that seed treatment with nano $\mathrm{ZnO}$ in combination with foliar application of nano ZnO @ 1000 ppm recorded significantly higher seed cotton yield than recommended practices. Significantly higher yield attributing character number of picked boll plant ${ }^{-1}$, seed cotton yield plant, seed cotton yield $\mathrm{kg} \mathrm{ha}^{-1}$ were reported by application of $125 \%$ RDF+foliar spraying of $0.5 \%$ Zinc $+0.2 \%$ Boron) twice during flowering and boll development stage (More et al., 2018). A field experiment conducted by Santhosh et al. (2016) revealed that soil application of $\mathrm{MgSO}_{4}$ and three foliar sprays of $\mathrm{MgSO}_{4}(1 \%)+\mathrm{KNO}_{3}(2 \%)$ recorded maximum seed cotton as compared to control (water spray). Field experiments were conducted for three years during Kharif, 2009-2011 to study the effect of foliar application of nutrients (N, Mg, Fe, Zn, Mn and B) on growth and yield parameters of $B t$ cotton and results of pooled data indicated highest seed cotton yield with application of $\mathrm{MgSO}_{4} 1.0 \%+$ $\mathrm{ZnSO}_{4}$ 0.5\% (Singh et al., 2015). The field experiment on effect of fertilizer levels on nutrient availability and yield of cotton on Vertisol was conducted at Rahuri and found that the application of $100 \% \mathrm{RDF}+1 \% \mathrm{MgSO}_{4}$ sprays recorded highest yield of $B t$ and non-Bt cotton hybrids (Deshpande et al., 2014).

Shivamurthy and Biradar (2014) conducted an experiment at Dharwad in medium black soils and revealed that application of $1 \%$ solution of 19:19:19 water soluble fertilizers at 70 , 90 and 110 DAS along with RDF+FYM+3 foliar sprays of $1 \%$ $\mathrm{MgSO}_{4}$ +soil application of $\mathrm{MgSO}_{4} @ 25 \mathrm{~kg} \mathrm{ha}^{-1}$ recorded significantly higher number of bolls plant ${ }^{-1}$ and boll weight over RDF+FYM+ water spray. At Hissar, a field experiment was conducted by Sukham et al. (2014) during kharif and recorded significantly higher number of bolls plant ${ }^{-1}$ and boll weight recorded with urea (2\%)+DAP (2\%)+MgSO $(1 \%)$ alternate spray over control. A field experiment conducted at Kanpur during kharif on sandy loam soil by Kumar and Yadav (2010) indicated that significantly higher number of bolls plant ${ }^{-1}$ and boll weight obtained with foliar application of $\mathrm{MgSO}_{4} @ 1 \%+\mathrm{ZnSO}_{4} @ 0.5 \%$ alternatively at boll formation stage over control. Sankaranarayanan et al. (2010) found that foliar application of $\mathrm{MgSO}_{4} @ 0.5 \%$ at 60,75 and 90 days after planting and borax @ 5 kg ha-1 (16 and 17\%) increased bursted bolls plant ${ }^{-1}(16 \%)$ and single plant yield (15.7\%) over control, same treatment recorded highest seed cotton yield in comparison to control.

\section{Effect of Secondary and Micro Nutrients on Quality of Cotton}

Significantly higher ginning value was obtained from control 
(46.20\%), while the lowest value was obtained from the foliar application of boron (2000 cc ha-1) at boll formation period (44.95\%) (Karademir and Karademir, 2020). A field experiment conducted by Rahman et al. (2018), resulted that highest (40.52\%) ginning out turn (GOT) was recorded due to the foliar application of $1.0 \mathrm{~g} \mathrm{~B} \mathrm{I}^{-1}$ whereas the lowest (39.09\%) ginning out turn was observed with $1.75 \mathrm{~g} \mathrm{~B}^{-1}$ spray. Rajput et al. (2016) conducted laboratory studies and noticed that, there was no significant effect of micronutrient on lint quality characters such as fibre maturity, staple length, seed index, GOT and seed germination, but micronaire and fibre strength were significantly affected. Raju and Thakare (2012) in an experiment at CICR, Nagpur found that fibre properties of cotton were not significantly influenced by micro and secondary nutrients either through soil or foliar application except $\mathrm{ZnSO}_{4} @ 25 \mathrm{~kg} \mathrm{ha}^{-1}$ soil application reduced span length by $1 \mathrm{~mm}$. A field experiment conducted at Madurai on clay loam soil during summer under irrigated conditions by Rajendran et al. (2011) and it was noticed that foliar nutrition of micronutrients did not influence the quality characters of cotton like seed index, lint index, ginning percentage, bundle strength and fibre finness.

\section{Conclusion}

For Bt-cotton, a lot of work has been done in developing optimum levels of NPK fertilizers, but there is a lack of interest in determining the adequate levels of micro-nutrients for its sustainable production. Judicious and balanced use of micro and macronutrients in Bt-cotton can substantially improve the growth, boll diameter, number of bolls per plant, fiber quality, nutrient uptake and seed cotton yield.

\section{References}

CICR., 2009. Annual Report of All India Coordinated Cotton Improvement Project. Central Institute for Cotton Research (CICR). Coimbatore, TN, India.

Deshpande, A.N., Masram, R.S., Kamble, B.M., 2014. Effect of fertilizer levels on nutrient availability and yield of cotton on Vertisol at Rahuri, District Ahemadnagar, India. Journal of Applied and Natural Science 6(2), 534-540.

Karademir, E., Karademir, C., 2020. Effect of different boron application on cotton yield components and fiber quality properties. Cercetări Agronomice în Moldova 4(180), 341-352.

Kumar, J., Yadav, M.P., 2010. Effect of foliar application of nutrients on seed cotton yield and economics in Hirsutum cotton. Journal of Cotton Research and Development 24(1), 71-72.

More, V.R., Khargkharate, V.K., Yelvikar, N.V., Matre, Y.B., 2018. Effect of boron and zinc on growth and yield of $B t$. cotton under rainfed condition. International Journal Pure Applied Bioscience 6(4), 566-570.

Rahman, M. T., Haque, M. M., Mortuza, M.G.G., Hossain, M.S., Chakraborty, R., 2018. Influence of Foliar Boron
Application on Ginning Traits, Fiber and Seed Quality of Cotton. Journal of Experimental Agriculture International 23(1), 1-6.

Raj, N.P., Chandrashekara, C.P., 2019. Nano Zinc Seed Treatment and Foliar Application on Growth, Yield and Economics of Bt Cotton (Gossypium hirsutum L.). International Journal of Current Microbiology and Applied Sciences 8(8), 1624-1630.

Rajendran, K., Mohamed Amanuallah, M., Vaiyapuri, K., 2011. Influence on growth, yield attributes and yield of $B t$ cotton by soil and foliar application of nutrients. Madras Agricultural Journal 98(1-3), 67-68.

Rajput, L.B., Gilal, A.A., Abro, G.H., Mastoi, M. I., Sahito, J.G.M., Nizamani, I.A., 2016. Effect of application of micronutrients on the lint quality parameters of cotton. Science International (Lahore) 28(2),1295-1298.

Raju, A.R., Thakare, S.K., 2012. Effect of nutrient management on FUE, red leaf, fibre properties of $B t$ hybrid cotton (Gossypium hirustum). Indian Journal of Agronomy 57(4), 390-396.

Ratna Kumari, S., Hema, K., 2009. Influence of foliar application of certain nutrients on yield and quality of cotton in black cotton soils under rainfed conditions. Journal of Cotton Research and Development 23(1), 88-92.

Sankaranarayanan, K., Praharaj, C.S., Nalayini, P., Bandyopadhyay, K.K., Gopalakrishnan, N., 2010. Effect of magnesium, zinc, iron and boron application on yield and quality of cotton (Gossypium hirsutum). Indian Journal of Agricultural Sciences 80(8), 699-703.

Santhosh, U.N., Rao, S., Biradar, S.A., Desai, B.K., Halepyati, A.S., Koppalkar, B.G., 2016. Response of soil and foliar nutrition on Bt cotton (Gossypium hirsutum L.) quality, yield parameters and economics under irrigation. Journal of Cotton Research and Development 30(2), 205-209.

Santhosh, U.N., Rao, S., Desai, B.K., Halepyati, A.S., Koppalkar, B.G., 2015. Effect of nutrient management practices on leaf reddening of $B t$ cotton (Gossypium hirustum L.) under irrigated conditions. Journal of Cotton Research and Development 29(1), 71-75.

Shivamurthy, D., Biradar, D.P., 2014. Effect of foliar nutrition on growth, yield attributes and seed cotton yield of Bt cotton. Karnataka Journal of Agricultural Sciences 27(1), 5-8.

Singh, K., Rathore, P., Gumber, P.K., 2015. Effects of foliar application of nutrients on growth and yield of $B t$ cotton (Gossypium hirsutum L.). Bangladesh Journal of Botany 44(1), 9-14.

Sukham, M., Siwach, S.S., Sangwan, R.S., Sangwan, O., Chauhan, D., Pundir, S.R., Jain, A., Wadhwa., 2014. Effect of foliar spray of nutrients on morphological and Physiological parameters. International Journal of Agricultural Sciences 28(2), 268-271. 